\title{
PENGARUH IMPLEMENTASI TOTAL QUALITY MANAGEMENT (TQM) TERHADAP KEPUASAN NASABAH PADA PERBANKAN KONVENSIONAL BANK TABUNGAN NEGARA (BTN) KCP UIN SUNAN AMPEL SURABAYA
}

\author{
Yosinta Damayanti \\ Universitas Islam Negeri Sunan Ampel Surabaya \\ yosinta.damayanti07@gmail.com
}

\begin{abstract}
The current era of globalization requires companies to participate in global competition. It takes an insight or science and technology to be able to make developments for the company and its resources in order to compete. Talking about globalization cannot be separated from the banking sector. The financial sector itself plays a very important role in triggering the economic growth of a region. The contribution of the banking sector cannot be separated from the support for the world of education, especially the cooperation between universities and the banking sector to improve service to students. One way to achieve customer satisfaction is by providing value in the form of the application of the Total Quality Management (TQM) method. The purpose of this study was to explain the effect of Total Quality Management (TQM) on customer satisfaction in conventional banking at the State Savings Bank, KCP UIN Sunan Ampel, Surabaya. This research uses quantitative methods with descriptive analysis and simple linear regression as a test of influence. The results of this study state that Total Quality Management (TQM) can significantly and positively affect Customer Satisfaction.
\end{abstract}

Keyword : TQM, customer satisfaction.

\section{PENDAHULUAN}

Era globalisasi yang terjadi saat ini menuntut perusahaan untuk terjun dalam persaingan global. Dibutuhkan suatu wawasan atau ilmu serta teknologi untuk dapat melakukan perkembangan bagi perusahaan dan sumber daya didalamnya agar dapat bersaing. Apabila suatu perusahaan tidak dapat mengimbangi persaingan global yang terus meningkat, maka perusahaan tersebut akan mengalami kemunduran dan perlahan-lahan akan menuju kebangkrutan. Menghadapi persaingan global diperlukan peran serta semua pihak baik dari pihak pemerintah, perusahaan, dunia pendidikan, maupun masyarakat. Selain itu perlu pula diketahui tujuan persaingan, bagaimana menciptakan keunggulan bersaing dan menyusun strategi untuk memasuki pasar global (Ninuk Mulyani, 2002, p.261). Oleh karena itu, terdapat suatu solusi yang dapat dilakukan oleh perusahaan yaitu dengan melakukan peningkatan pada kualitas perusahaan, baik itu dari segi sumber daya manusia, ataupun proses manajerial perusahaan. Hal tersebut dilakukan dengan tujuan untuk mendapatkan nilai tambah bagi output (dapat berupa produk ataupun jasa) yang dikeluarkan perusahaan.

Berbicara tentang globalisasi tak lepas dari sektor perbankan. Sektor keuangan sendiri memegang peranan yang sangat penting dalam memicu pertumbuhan ekonomi suatu daerah. Menurut Bank Dunia, sektor keuangan yang semakin berkembang diyakini dapat mendorong pertumbuhan ekonomi, menurunkan kemiskinan, dan meredam volatilitas ekonomi makro. Namun rekomendasi tersebut masih menimbulkan perdebatan baik secara teori maupun secara empiris. Ada dua hal pokok yang masih diperdebatkan terkait perkembangan sektor keuangan, pertumbuhan ekonomi dan volatilitas ekonomi makro (Utami Baroroh, 2012, p.181). Kontribusi sektor perbankan tak lepas dari dukungan terhadap dunia pendidikan, terlebih adanya kerjasama antara perguruan tinggi dengan Sektor Perbankan untuk meningkatkan layananan terhadap mahasiswa.

Salah satu dari contoh perusahaan yang bersaing di era globalisasi ini ada pada perusahaan dibidang perbankan yaitu Bank Tabungan Negara (BTN). Bank adalah suatu lembaga keuangan yang bertujuan untuk meningkatkan taraf hidup masyarakat dengan melakukan kegiatan menghimpun dana yang berasal dari masyarakat dan kemudian menyalurkan dana tersebut kepada masyarakat yang memerlukan dana. Sedangkan Bank Tabungan Negara (BTN) merupakan bank yang berfokus untuk 
konsumen dengan segmen menengah kebawah. Selain itu, Bank Tabungan Negara (BTN) juga berfokus pada segmen milenial yang salah satunya adalah mahasiswa. Sebagai bank yang menjadi partner bagi Perguruan Tinggi di indonesia tentunya tingkat penggunaan rekening oleh mahasiswa di UIN Sunan Ampel Surabaya secara kuantitas dapat diperhitungkan.

Dari tahun ke tahun, bidang perbankan selalu dihadapkan pada kondisi dimana tingkat kebutuhan masyarakat akan jasa simpan pinjam semakin meningkat. Kondisi tersebut menjadikan persaingan pada bidang perbankan menajadi semakin ketat terutama dengan adanya Financial Technology (fintech) yang juga bertumbuh semakin pesat. Perkembangan berbagai layanan keuangan digital yang berasal dari perusahaan non-bank atau perusahaan start-up yang dapat diakses dimana saja dan kapan saja akan mengancam eksistensi dari perbankan konvensional itu sendiri, termasuk pada Bank Tabungan Negara (BTN). Pada kondisi tersebut, akan sangat krusial bagi perusahaan pada bidang perbankan untuk terus melakukan perbaikan berkelanjutan dalam hal pemberikan layanan pada nasabahnya agar dapat mempertahankan nasabahnya ataupun agar dapat memperoleh nasabah yang baru. Nasabah akan dapat bertahan pada suatu bank apabila bank tersebut dapat memenuhi harapannya sehingga nasabah merasa puas.

Salah satu cara agar dapat mencapai kepuasan bagi pelanggan adalah dengan memberikan value yang dapat berasal dari pelayanan ataupun sistem dalam manajemen yang dapat mempengaruhi emosi nasabah. Value tersebut dapat diciptakan dengan penerapan metode Total Quality Management (TQM). Manfaat TQM adalah memperbaiki kinerja manajerial dalam mengelola perusahaan agar dapat meningkatkan penghasilan perusahaan. Ada beberapa keuntungan pengendalian mutu yang digambarkan Ishikawa pada 1993 dalam bukunya, antara lain pengendalian mutu memungkinkan untuk membangun mutu di setiap langkah proses produksi demi menghasilkan produk yang $100 \%$ bebas cacat dan Pengendalian mutu memungkinkan perusahaan menemukan kesalahan atau kegagalan sebelum akhirnya berubah menjadi musibah bagi perusahaan (Maddeppungeng dkk, 2016, p.88).

Berdasarkan pembahasan terkait latar belakang diatas, penulis tertarik untuk melakukan penelitian yang mengangkat pengaruh total quality management (TQM) terhadap kepuasan nasabah perbankan dengan judul "Pengaruh Implementasi Total Quality Management (TQM) Terhadap Kepuasan Nasabah pada Perbankan Konvensional Bank Tabungan Negara (BTN) Kcp UIN Sunan Ampel Surabaya".

Sedangkan terkait dengan rumusan masalah dalam penelitian ini adalah apakah Total Quality Management (TQM) memiliki pengaruh positif terhadap kepuasan nasabah pada perbankan konvensional Bank Tabungan Negara KCP UIN Sunan Ampel Surabaya. Penelitian ini dilakukan dengan tujuan untuk menjelaskan pengaruh dari Total Quality Management (TQM) terhadap kepuasan nasabah pada perbankan konvensional Bank Tabungan Negara KCP UIN Sunan Ampel Surabaya. Penelitian ini diharapkan dapat menjadi referensi ataupun rujukan untuk semakin mendorong kemajuan total quality management (TQM) dalam perusahaan yang berbentuk perbankan konvensional sehingga dapat memberikan pengaruh positif bagi kepuasan nasabahnya.

\section{TINJAUAN PUSTAKA}

\section{Total Quality Management (TQM)}

Pengertian Total Quality Management (TQM)

Kualitas selalu menjadi titik fokus dan keutamaan dalam setiap perusahaan untuk meraih kesuksesan. Perusahaan selalu berupaya untuk meningkatkan kualitas outputnya, baik itu pada produk, pelayanan, ataupun manajemen dalam perusahaan. Kotler mendefinisikan kualitas sebagai suatu keadaan dinamis 
yang berkaitan dengan produk, jasa, sumber daya manusia, proses, serta lingkungan yang memenuhi harapan (Madona, 2017, p.21). Dari pengertian tersebut dapat diartikan bahwa perbaikan dan pengembangan kualitas bagi perusahaan merupakan prioritas dan tantangan yang harus terus dilakukan. Seiring dengan berkembangnya ilmu pengetahuan, telah hadir suatu inovasi dalam perbaikan dan pengembangan kualitas yang dikenal dengan total quality management (TQM).

Penting bagi perusahaan untuk melakukan upaya perbaikan berkesinambungan pada kualitas, hal tersebut menunjukkan perlunya pengelolaan kualitas yang salah satu metodenya adalah menggunakan total quality management (TQM). Menurut Heizer dan Render, total quality management (TQM) mengarah pada penekanan kualitas organisasi secara menyeluruh, baik itu dari pemasok sampai pada pelanggan (Jey Heizer \& Barry Render, 2009, p.4). Definisi lain TQM yaitu menurut Ross adalah integrasi dari seluruh proses dan fungsi organisasi dalam rangka pencapaian perbaikan dan peningkatan kualitas secara berkesinambungan pada produk baik itu berbentuk barang ataupun layanan. Gagasan tersebut dapat berarti bahwa kualitas harus dilihat dari segala fungsi perusahaan dan dilakukan secara terintegrasi yaitu mulai dari proses awal hingga proses akhir (Setiawan, 2018, p.6). Sedangkan Khim dan Larry dalam Bismar Harris Setiawan (2018, p.4) mendefinisikan total quality management (TQM) sebagai suatu konsep yang mengacu pada peningkatan berkelanjutan pada proses pemanufakturan yaitu dengan meminimalisir pemborosan, manaikkan kualitas, serta melakukan pengembangan keterampilan dan melakukan pengurangan pada biaya produksi. Sedangkan Rivai (2008, p.62) mengemukakan bahwa total quality management (TQM) merupakan suatu konsep yang membutuhkan komitmen serta keterlibatan yang berasal dari pihak manajemen dan semua pengelola perusahaan dalam pemenuhan keinginan konsumen yang dilakukan secara konsisten.

Dari beberapa definisi terkait total quality management (TQM) tersebut dapat disimpulkan bahwa TQM adalah salah satu metode yang digunakan dalam manajemen kualitas yaitu dengan melakukan program perbaikan kualitas secara berkesinambungan dan terintegrasi dengan melibatkan segala fungsi dalam organisasi untuk dapat mencapai kepuasan pelanggan secara berkelanjutan (sustainable satisfaction).

\section{Unsur-Unsur dalam Total Quality Management (TQM)}

Apabila dikaitkan dengan implementasinya, TQM tidak dapat terlepas dari karakteristik yang dimilikinya, yang tentunya dapat memberikan dampak positif bagi perusahaan ataupun pelanggan. Goetsch dan Davis dalam Nasution (2015, p.22) mengembangkan sepuluh karakteristik dari total quality management (TQM), yaitu diantaranya:

1. Fokus Pada Konsumen

2. Obsesi terhadap Kualitas

3. Pendekatan Ilmiah

4. Komitmen Jangka Panjang

5. Kerjasama Tim (Teamwork)

6. Perbaikan Sistem Secara Berkesinambungan

7. Pendidikan dan Pelatihan

8. Kebebasan yang Terkendali

9. Kesatuan Tujuan

10. Adanya Keterlibatan dan Pemberdayaan Karyawan (Umi Elan, 2016, p.179). 


\section{Prinsip-Prinsip Total Quality Management (TQM)}

Selain memiliki karakteristik, TQM juga memiliki prinsip-prinsip utama dalam pelaksanaannya. Berikut merupakan prinsip total quality management menurut Hensler dan Brunell dalam Nasution (2010, p.30-31):

\section{Kepuasan bagi Konsumen}

Kepuasan bagi konsumen merupakan suatu hal penting dalam implementasi TQM. Perusahaan akan senantiasa berusaha untuk menciptakan produk yang dapat memenuhi kebutuhan konsumen melalui pengkoordinasian segala aktivitas agar dapat memuaskan konsumennya. Hal tersebut dilakukan untuk memberikan kepuasan bagi konsumen dari beberapa aspek, yaitu pada aspek harga, keamanan, maupun ketepatan waktu.

\section{Respek terhadap Setiap Orang}

Respek terhadap setiap orang dapat dikatakan sebagai hal yang penting bagi perusahaan, terutama bagi perusahaan yang memiliki golongan kualitas kelas dunia. Dalam prinsip ini, setiap karyawan dalam organisasi atau perusahaan akan memperoleh perlakuan yang baik dan diberikan kesempatan untuk dapat mengambil keputusan. Hal tersebut disebabkan karena setiap karyawan dalam organisasi/perusahaan akan dilihat sebagai seorang yang memiliki kemampuan dan kreativitas khas.

\section{Manajemen Fakta}

Dalam pelaksanaan TQM, setiap pengambilan keputusan dalam perusahaan selalu berdasarkan pada fakta (data). Dalam prinsip ini, terdapat dua konsep pokok yakni pertama prioritas atau konsep yang menjelaskan bahwa suatu perbaikan tidak bisa dilaksanakan pada saat bersamaan pada segala aspek, hal tersebut dikarenakan adanya keterbatasan sumber daya. Maka dari itu, dibutuhkan data bagi perusahaan agar perusahaan dapat fokus pada hal-hal yang vital. Sedangkan konsep yang kedua yaitu variabilitas kinerja manusia, dalam konsep ini data akan menggambarkan variabilitas pada tiap-tiap sistem manajemen dalam perusahaan. gambaran tersebut akan menunjukkan apakah variabilitas telah sesuai atau wajar. Oleh karena itu, manajemen fakta dapat memberikan prediksi yang cenderung tepat dan akurat dalam setiap tindakan dan proses pengambilan keputusan (Tjiptono \& Anastasia, 1995, p. 13-15).

\section{Perbaikan Berkesinambungan}

Untuk mencapai kesuksesan, diperlukan perbaikan berkesinambungan yang dilakukan secara sistematis pada perusahaan. Dalam prinsip ini, dibutuhkan keterlibatan semua komponen perusahaan untuk melakukan perencanaan, serta kemudian melaksanakan tindakan-tindakan yang menunjukkan perbaikan pada hasil.

\section{Kepuasan Nasabah}

\section{Pengertian Kepuasan Nasabah}

Suatu kepuasan dapat diperoleh dari hasil pemenuhan harapan konsumen melalui kinerja dari perusahaan yang diberikan kepadanya. Pengertian dari kepuasan sendiri dikemukakan oleh Kotler dan Keller (2000, p.42) yaitu merupakan rasa senang ataupun kecewa yang dirasakan seseorang, dimana perasaan tersebut timbul setelah melakukan perbandingan antara persepsi atau kesan pada hasil kinerja suatu produk beserta harapannya. Dari pengertian tersebut, dapat diketahui bahwa apabila 
kinerja yang diberikan suatu produk ada di bawah harapan konsumen, maka konsumen tidak merasa puas, begitu pula sebaliknya.

Kepuasan sangat erat kaitannya dengan seorang konsumen, atau yang dalam penelitian ini merupakan nasabah. Sama halnya dengan konsep kepuasan, kepuasan nasabah akan memberikan dampak yang baik bagi perusahaan. hal tersebut disebabkan karena kepuasan nasabah akan sangat berperan pada beberapa aspek perusahaan seperti meningkatkan hubungan yang harmonis antara perusahaan dan pelanggan, menciptakan loyalitas pada nasabah, memberikan peningkatan pada reputasi perusahaan, maupun peningkatan pada produktivitas karyawan perusahaan. Fandy Tjiptono (2009, p.146) mengemukakan definisi kepuasan nasabah sebagai penilaian atau evaluasi setelah melakukan pembelian disaat alternatif yang dipilih setidaknya memberikan hasil yang sama bahkan melebihi harapan nasabah. Sedangkan Supranto (2009, p.233) mendefinisikan kepuasan nasabah sebagai tingkatan perasaan seseorang sesudah melakukan perbandingan antara kinerja dan hasil yang diberikan dengan harapan yang diinginkan. Dari beberapa definisi tersebut, dapat ditarik kesimpulan bahwa kepuasan yang dirasakan oleh nasabah diperoleh dengan membandingkan antara kinerja yang diberikan dengan harapan yang dimiliki oleh nasabah tersebut. Perasaan puas akan diperoleh apabila kinerja yang diberikan telah sesuai dengan harapan nasabah, begitu pula sebaliknya, perasaan tidak puas pada nasabah akan timbul pada saat kinerja yang diberikan tidak dapat memenuhi harapan nasabah.

Indikator yang Digunakan untuk Mengukur Kepuasan Nasabah

Dalam pembelajaran bidang pemasaran, kepuasan nasabah selalu menjadi fokus sentral pada teori ataupun praktiknya. Sedangkan dalam implementasinya, kepuasan nasabah dapat menjadi suatu tujuan dari aktivitas-aktivitas yang dilakukan perusahaan. Sulitnya mempertahankan seorang pelanggan dapat menjadi salah satu penyebab kepuasan pelanggan menjadi penting untuk diperhatikan. Dalam mengukur kepuasan pelanggan, terdapat beberapa indikator yang dikemukakan oleh Irawan (2004, p.37) yakni berupa lima dimensi utama, yaitu sebagai berikut:

\section{Harga}

Harga akan mempengaruhi tingkat kepuasan pelanggan apabila pelanggan merupakan seseorang yang sensitif terhadap harga yang murah, dengan kata lain bahwa harga yang lebih murah akan membuat tingkat kepuasan pelanggan menjadi lebih tinggi.

2. Kualitas pelayanan (service quality)

Kualitas layanan dapat terdiri dari tangible, responsif, keandalan, jaminan, dan empati. Perusahaan yang memiliki kualitas layanan yang baik akan membuat tingkat kepuasan pelanggan menjadi lebih tinggi.

\section{Kualitas produk}

Kualitas produk dapat diartikan sebagai pengemudi dalam dimensi kepuasan pelanggan, dimana pelanggan akan merasakan kepuasan apabila produk yang diperoleh memiliki kualitas yang baik.

\section{Faktor emosional}

Faktor emosional dapat diartikan sebagai rasa bangga atau rasa percaya diri yang berkaitan dengan gaya hidup seseorang dalam melakukan pembelian atau penggunaan sebuah jasa.

5. Kemudahan (efficiency) 
Kemudahan dalam kepuasan pelanggan dapat diartikan apabila produk atau layanan sifat yang relatif mudah didapatkan, nyaman, serta efisien, maka tingkat kepuasan pelanggan akan semakin tinggi.

Hubungan antara Total Quality Management (TQM) dengan Kepuasan Nasabah

Total Quality Management (TQM) dapat diterapkan pada setiap perusahaan yang ingin melakukan perkembangan kualitas produknya, baik itu produk yang berupa barang ataupun jasa. Pelaksanaan TQM sendiri tentunya selalu diarahkan agar perusahaan dapat mencapai kepuasan pelanggannya, sehingga pelanggan akan tetap bertahan menggunakan produk perusahaan tersebut. TQM dapat dikatakan memiliki hubungan yang sangat erat dengan kepuasan pelanggan, karena kepuasan pelanggan atau yang dalam penelitian ini disebut sebagai kapuasan nasabah merupakan salah satu dari prinsip TQM yang dikemukakan oleh Hensler dan Brunell.

Terkait dengan hubungan antara TQM dan kepuasan nasabah tersebut, penelitian yang dilakukan oleh Erry Donneli (2018) di Gazebo Garden Restaurant Purawisata Yogyakarta memberikan hasil bahwa Total Quality Management (TQM) memiliki pengaruh yang positif terhadap kepuasan pelanggan. Hasil tersebut dibuktikan dengan uji koefisien determinasi (R2) yang menunjukkan hasil 0,768, dimana hasil tersebut berarti bahwa TQM dapat mempengaruhi kepuasan pelanggan sebesar 76,8\%. Hasil dari penelitian tersebut juga didukung oleh penelitian sebelumnya yang dilakukan oleh Ria Amalia Sukardi (2016). Ria melakukan penelitian terkait pengaruh TQM pada kepuasan pelanggan pada Matahari Department Store di Plaza Mulia Samarinda. Penelitian tersebut menunjukkan bahwa Total Quality Management (TQM) dapat mempengaruhi kepuasan pelanggan secara signifikan. Dari dua hasil penelitian terdahulu tersebut, peneliti berusaha membuktikan kebenaran bahwa Total Quality Management (TQM) memiliki pengaruh yang positif terhadap kepuasan nasabah, yang dalam penelitian ini adalah nasabah dari Bank Tabungan Negara (BTN) Kcp UIN Sunan Ampel Surabaya.

\section{Kerangka Konseptual}

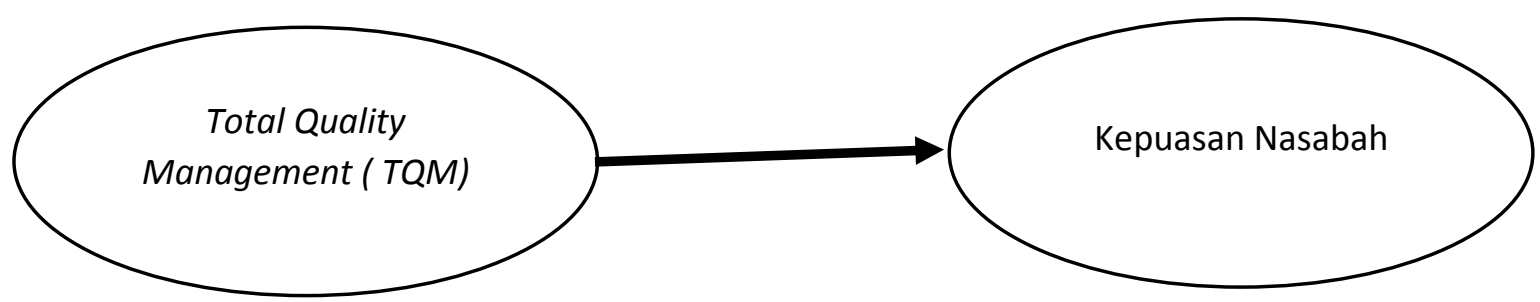

\section{Hipotesis}

Hipotesis dapat berupa alasan ataupun pengutaraan pendapat seperti teori, preposisi, dan lain sebagainya. Berdasar pada tinjauan pustaka dan kerangka konseptual, maka hipotesis dalam penelitian ini adalah:

Ho : Tidak terdapat pengaruh positif antara total quality management (TQM) (X1) terhadap kepuasan nasabah perbankan konvensional Bank Tabungan Negara (BTN) KCP UIN Sunan Ampel Surabaya (Y1).

Ha : Terdapat pengaruh positif antara total quality management (TQM) (X1) terhadap kepuasan nasabah perbankan konvensional Bank Tabungan Negara (BTN) KCP UIN Sunan Ampel Surabaya (Y1).

\section{METODE PENELITIAN}

Jenis penelitian yang digunakan dalam penelitian ini adalah kuantitatif dengan menggunakan pendekatan korelasional dan menggunakan metode explanatory survey atau survei eksplanasi. 
Penelitian ini digunakan untuk mengetahui pengaruh antara total quality management (TQM) terhadap kepuasan nasabah Bank Tabungan Negara (BTN) KCP UIN Sunan Ampel Surabaya.

\section{Teknik Pengumpulan Data}

Data dapat diartikan sebagai bahan yang akan digunakan untuk menjawab permasalahan penelitian. Dalam penelitian ini, jenis data yang dikumpulkan mencakup data yang bersifat primer dan data yang bersifat sekunder. Sedangkan teknik pengumpulan data yang digunakan pada penelitian ini adalah kepustakaan, observasi, dan pembagian kuesioner.

\section{Teknik Analisis Data}

Teknik analisis data yang digunakan pada penelitian ini adalah analisa kuantitatif dengan menggunakan metode statistik. Dalam penelitian ini, terdapat beberapa tahapan analisis data, yakni analisis deskriptif, uji asumsi klasik, uji pengaruh, dan uji hipotesis.

\section{HASIL DAN PEMBAHASAN}

\section{Uji Validitas dan Reliabilitas}

Suatu kuesioner akan dikatakan valid apabila pertanyaan pada kuesioner dapat mengungkapkan sesuatu yang diukur oleh kuesioner itu sendiri yang dalam hal ini diperlukan suatu uji untuk membuktikannya. Uji yang digunakan adalah uji validitas yang merupakan suatu skala pengukuran yang digunakan dengan tujuan mengetahui apakah suatu kuesioner dapat dikatakan valid atau tidak. Sedangkan uji reliabilitas merupakan alat dalam penelitian yang digunakan untuk mengukur kuesioner yang merupakan indikator dari variabel.

\section{a. Uji Validitas}

Uji validitas yang merupakan suatu skala pengukuran yang digunakan dengan tujuan mengetahui apakah suatu kuesioner dapat dikatakan valid atau tidak. Uji validitas dilakukan dengan melalui uji signifikansi dengan membandingkan nilai $r$-hitung dan nilai r-tabel. Apabila r-hitung lebih besar dari nilai r-tabel (atau dapat dirumuskan dengan r-hitung $>r$-tabel) dan memiliki nilai positif, maka variabel dalam penelitian dapat dinyatakan valid. Sedangkan apabila nilai r-hitung lebih kecil dari r-tabel (atau dapat dirumuskan dengan $r$-hitung $<$ r-tabel) dan memiliki nilai negatif, maka variabel dapat dinyatakan tidak valid (Ghozali, 2013, p.53). Berikut merupakan tabel hasil uji validitas kuesioner yang telah diolah, output dari uji validitas dalam SPSS 23 akan dipaparkan dalam lampiran.

Tabel Hasil Uji Validitas

\begin{tabular}{|c|c|c|}
\hline Pertanyaan & Koefisien Korelasi & Kesimpulan Hasil \\
\hline FPP_1 & 0,718 & Valid \\
\hline FPP_2 & 0,715 & Valid \\
\hline FPP_3 & 0,752 & Valid \\
\hline FPP_4 & 0,585 & Valid \\
\hline FPP_5 & 0,733 & Valid \\
\hline OTK_6 & 0,730 & Valid \\
\hline OTK_7 & 0,710 & Valid \\
\hline OTK_8 & 0,625 & Valid \\
\hline OTK_9 & 0,747 & Valid \\
\hline OTK_10 & 0,683 & Valid \\
\hline KP_11 & 0,728 & Valid \\
\hline KP_12 & 0,777 & Valid \\
\hline KP_13 & 0,811 & Valid \\
\hline KP_14 & 0,750 & Valid \\
\hline KP_15 & 0,740 & Valid \\
\hline K_16 & 0,816 & \\
\hline K_17 & 0,798 & Valid \\
\hline & & \\
\hline & & \\
\hline
\end{tabular}




\begin{tabular}{|c|c|c|}
\hline K_18 & 0,652 & Valid \\
\hline K_19 & 0,605 & Valid \\
\hline K_20 & 0,552 & Valid \\
\hline
\end{tabular}

Sumber: Output SPSS, diolah.

Nilai r-tabel untuk $\mathrm{N}=70$ dengan tingkat signifikansi sebesar 5\% atau 0,05 adalah 0,235. Berdasar pada data tabel diatas, dapat terlihat bahwa uji validitas yang dilakukan pada seluruh item sub-indikator dalam penelitian lebih besar dari r-tabel (r-hitung > r-tabel). Oleh karena itu, seluruh butir pertanyaan dalam kuesioner penelitian dapat dinyatakan valid.

\section{b. Uji Reliabilitas}

Langkah selanjutnya yang dilakukan setelah mengetahui hasil dari uji validitas adalah melakukan uji reliabilitas pada variabel. Uji reliabilitas dilakukan untuk mengetahui konsistensi dari jawaban yang diberikan responden. Berikut merupakan tabel hasil output dari uji reliabilitas dalam SPSS 23.

Tabel Hasil Uji Reliabilitas

Reliability Statistics

\begin{tabular}{|r|r|}
\hline $\begin{array}{c}\text { Cronbach's } \\
\text { Alpha }\end{array}$ & $\begin{array}{c}\text { N of } \\
\text { Items }\end{array}$ \\
\hline .957 & 20 \\
\hline
\end{tabular}

Sumber: Output SPSS

Suatu kuesioner akan dinyatakan reliabel apabila hasil dari cronbach's alpha $(\alpha)$ lebih besar dari 0,7. Hasil dari uji reliabel diatas memperlihatkan hasil dari cronbach's alpha $(\alpha)$ sebesar 0,957 , dimana hasil tersebut lebih besar dari 0,7 atau dapat dirumuskan dengan 0,957 >0,7. Oleh karena itu, maka seluruh variabel dalam kuesioner dinyatakan reliabel.

\section{Analisa Deskriptif}

Analisis diskriptif merupakan analisis yang dilaksanakan dengan tujuan agar dapat mengetahui dan dapat mendiskripsikan dengan menjelaskan karakteristik dari variabel yang diteliti berdasar pada data yang diperoleh (Sekaran, 2011, p.158). Analisis diskriptif yang merupakan prosedur olah data tersebut dilakukan dengan menggambarkan atau meringkas data melalui tabel atau grafik (Nursalam, 2008, p.120). Analisa diskriptif dalam penelitian ini akan disajikan dalam lampiran.

\section{Uji Asumsi Klasik}

\section{a. Uji Normalitas}

Uji normalitas dilakukan dengan tujuan untuk mengetahui normal atau tidaknya sebaran data pada variabel bebas (independen) dan variable terikat (dependen). Uji normalitas dalam penelitian ini menggunakan teknik kolmogorov-smirnov dengan alat bantu program SPSS versi 23. Berikut merupakan tabel output uji normalitas dalam SPSS 23: 
Tabel Hasil Uji Normalitas

One-Sample Kolmogorov-Smirnov Test

\begin{tabular}{|ll|r|}
\hline & & $\begin{array}{r}\text { Unstandardiz } \\
\text { ed Residual }\end{array}$ \\
\hline $\mathrm{N}$ & 70 \\
Normal Parameters & Mean & .0000000 \\
Most Extreme Differences & Std. Deviation & 2.06521539 \\
& Absolute & .091 \\
& Positive & .091 \\
Test Statistic & Negative & .063 \\
Asymp. Sig. (2-tailed) & & .091 \\
a. Test distribution is Normal. & $.200^{\text {c,d }}$ \\
\hline b. Calculated from data.
\end{tabular}

Sumber: Output SPSS

Data akan dikatakan memiliki distribusi normal apabila hasil perhitungan menyatakan nilai Signifikan lebih besar dari 0,05. Tabel hasil uji normalitas diatas dapat menunjukkan hasil uji sampel kolmogrov-smirnov dengan nilai asymp. Sig. sebesar 0,200. Nilai asymp. Sig. tersebut lebih besar dari 0,05 atau dapat dirumuskan dengan 0,200 >0,05. Oleh karena itu, data dapat dinyatakan berdistribusi normal.

\section{b. Uji Multikolinearitas}

Uji multikolinearitas berguna untuk mengetahui ada atau tidaknya korelasi atau hubungan antar variabel bebas (variabel dependen) pada model regresi. Terdapat dua tahap cara untuk mengetahui multikolinearitas yang digunakan dalam penelitian ini yaitu dengan analisis pada nilai tolerance dan dapat pula dengan VIF (Variance Influence Factor). Berikut merupakan tabel hasil uji multikolinearitas yang telah diolah, output dari uji multikolinearitas dalam SPSS 23 akan dipaparkan dalam lampiran:

\begin{tabular}{|c|c|c|}
\multicolumn{2}{c|}{ Tabel Hasil Uji Multikolinearitas } \\
\hline Variabel Penelitian & VIF & Tolerance \\
\hline $\begin{array}{c}\text { Total Quality } \\
\text { Management } \\
\text { (TQM) }\end{array}$ & 1,000 & 1,000 \\
\hline
\end{tabular}

Sumber: Output SPSS, diolah.

Dalam uji multikolinearitas dengan nilai tolerance dan VIF memiliki ketentuan yaitu apabila nilai VIF lebih besar dari 10 dan nilai tolerance pada seluruh variabel independen lebih kecil dari 0,1 , artinya terdapat masalah multikolinearitas pada variabel independen. Begitu pula sebaliknya, yakni apabila nilai VIF lebih kecil dari 10 dan nilai tolerance pada seluruh variabel independen lebih besar dari 0,1, artinya tidak terdapat masalah multikolinearitas pada variabel independent (Supriyanto, 2013, p.71). Hasil dari uji multikolinearitas dengan SPSS versi 23 menunjukkan bahwa nilai VIF lebih kecil dari 10 dan nilai Tolerance memiliki nilai lebih besar dari 0,1 . Oleh karena itu, dapat dinyatakan bahwa dalam penelitian dan variabel independent (bebas) tidak memiliki masalah multikolinearitas.

\section{c. Uji Autokorelasi}

Uji autokorelasi termasuk salah satu uji yang ada dalam uji asumsi klasik dalam model regresi yang berguna untuk menguji ada atau tidaknya korelasi antara kesalahan pengganggu pada periode $\mathrm{t}$ (saat ini) dengan kesalahan pada periode t-1 (periode sebelumnya). Sedangkan terkait dengan penggunaan asumsi pada uji autokorelasi menurut Ghozali (2016, p.107) yaitu menggunakan uji Durbin Watson, dimana uji tersebut menghasilkan nilai durbin watson (dw) dan nilai durbin watson table yang meliputi durbin upper (du) dan durbin lower ( $\mathrm{dl}$ ), dengan ketentuan bahwa: 
1. Apabila nilai $\mathrm{dw}<\mathrm{dl}$ atau nilai $\mathrm{dw}>4-\mathrm{dl}$, maka terdapat autokorelasi.

2. Apabila nilai $\mathrm{du}<\mathrm{dw}<4$-du, maka tidak terdapat autokorelasi.

3. Apabila nilai 4-du $<\mathrm{dw}<4$-dl atau nilai $\mathrm{dl}>\mathrm{dw}>\mathrm{du}$, maka hasil tidak dapat disimpulkan.

Berikut merupakan tabel output uji autokorelasi dalam SPSS 23:

\section{Tabel Hasil Uji Autokorelasi}

Model Summary ${ }^{b}$

\begin{tabular}{|l|c|r|r|r|r|}
\hline Model & $\mathrm{R}$ & $\mathrm{R}$ Square & \multicolumn{1}{c|}{$\begin{array}{c}\text { Adjusted R } \\
\text { Square }\end{array}$} & $\begin{array}{c}\text { Std. Error of the } \\
\text { Estimate }\end{array}$ & Durbin-Watson \\
\hline 1 & $.901^{\mathrm{a}}$ & .812 & .809 & 2.08035 & 1.864 \\
\hline
\end{tabular}

a. Predictors: (Constant), TQM

b. Dependent Variable: KEPUASANNASABAH

\section{Sumber: Output SPSS}

Berdasar pada hasil uji autokorelasi menggunakan SPSS 23, dapat dilihat bahwa nilai d adalah sebesar 1,864. Kemudian berdasar pada tabel Durbin Watson, dengan jumlah responden $(\mathrm{N})=70$, dan jumlah variabel bebas $(\mathrm{K})=1$ dan dengan Alpha 0,05 atau 5\%, maka diperoleh nilai $\mathrm{dU}=1,641$, dan $\mathrm{dL}=1,583$, serta nilai 4-dU $=2,358$. Oleh karena itu, dapat dirumuskan bahwa $\mathrm{dU}<\mathrm{d}<4$-dU, sehingga dapat disimpulkan bahwa tidak terdapat autokorelasi.

\section{d. Uji Heteroskedisitas}

Uji heteroskedastisitas termasuk salah satu uji yang ada dalam uji asumsi klasik yang bertujuan untuk menguji ada atau tidaknya perbedaan varians pada residual suatu pengamatan ke pengamatan lainnya dalam model regresi (Akila, 2017, p.40). Dalam penelitian ini, uji heteroskedastisitas dilakukan dengan alat bantu program SPSS 23. Heteroskedastisitas dapat dideteksi dengan melihat grafik scatterplot pada output SPSS. Apabila terdapat pola tertentu pada grafik scatterplot berupa titik-titik yang berpola teratur, maka pola tersebut menunjukkan terjadinya heteroskedastisitas. Begitu pula sebaliknya, apabila tidak terdapat pola yang jelas berupa titik-titik yang menyebar diatas dan dibawah angka nol serta tidak pula mengumpul hanya di atas saja ataupun di bawah saja, maka pola tersebut menunjukkan tidak terjadi heteroskedastisitas. Suatu model analisis regresi dapat dikatakan baik apabila tidak terjadi heteroskedastisitas, berikut merupakan grafik output uji heteroskedastisitas dalam SPSS 23:

\section{Grafik Hasil Uji Heteroskedastisitas}

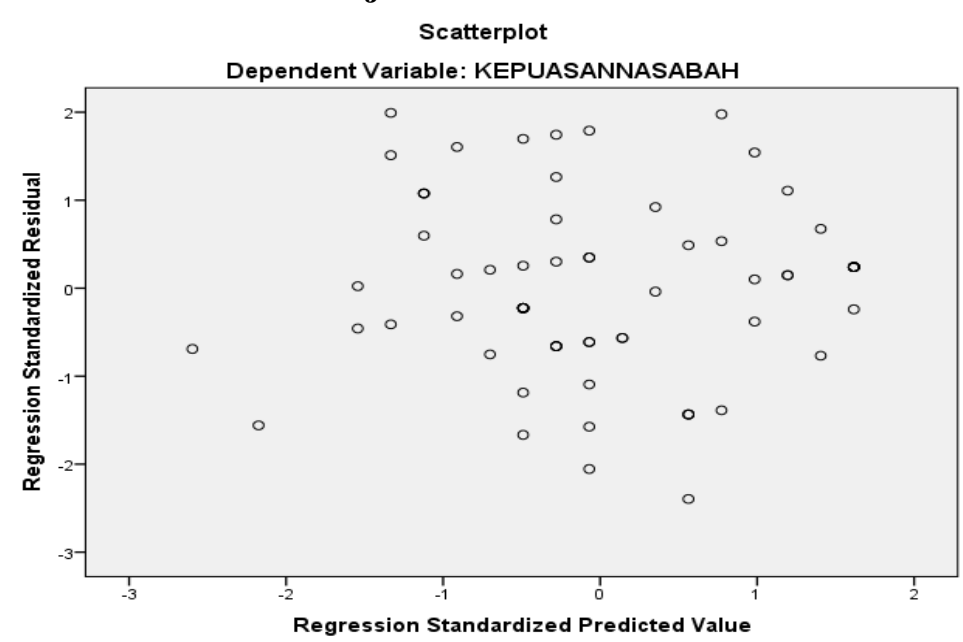

Sumber: Output SPSS 
Berdasar pada hasil grafik scatterplot tersebut, terlihat bahwa titik-titik membentuk pola yang tidak jelas dan titik-titik menyebar (acak). Oleh karena itu, dapat disimpulkan bahwa tidak terjadi heteroskedastisitas.

\section{Uji Pengaruh}

\section{a. Analisis Regresi Linier Sederhana}

Analisis regresi linier sederhana digunakan untuk mengetahui secara linier hubungan antar variabel yaitu variabel independent dan variabel dependen. Dalam penelitian ini, analisis regresi linier sederhana dilakukan dengan alat bantu SPSS 23. Rumus regresi linear sederhana dapat menggunakan persamaan $\mathbf{Y}=\mathbf{a}+\mathbf{b X}$. Berikut merupakan tabel output regresi dalam SPSS 23:

Tabel Hasil Analisis Regresi Linier Sederhana

Coefficients $^{a}$

\begin{tabular}{|c|c|c|c|c|c|c|c|c|}
\hline \multirow[b]{2}{*}{ Model } & & \multicolumn{2}{|c|}{ Unstandardized Coefficients } & \multirow{2}{*}{$\begin{array}{c}\begin{array}{c}\text { Standardized } \\
\text { Coefficients }\end{array} \\
\text { Beta } \\
\end{array}$} & \multirow[b]{2}{*}{$\mathrm{t}$} & \multirow[b]{2}{*}{ Sig. } & \multicolumn{2}{|c|}{ Collinearity Statistics } \\
\hline & & $B$ & Std. Error & & & & Tolerance & VIF \\
\hline 1 & (Constant) & 4.341 & 2.247 & & 1.932 & .058 & & \\
\hline & TQM & .903 & .053 & .901 & 17.123 & .000 & 1.000 & 1.000 \\
\hline
\end{tabular}

a. Dependent Variable: KEPUASANNASABAH

\section{Sumber: Output SPSS}

Dari hasil tersebut, terlihat bahwa variabel Total Quality Management (TQM) memiliki koefisien sebanyak 0,903 , sehingga dapat disusun persamaan regresi linier sederhana yaitu $\mathbf{Y}=\mathbf{4 , 3 4 1}+\mathbf{0 , 9 0 3 X}$. Dari persamaan regresi linier sederhana tersebut, dapat diambil suatu kesimpulan bahwa apabila tingkat Total Quality Management (TQM) semakin baik maka tingkat Kepuasan Nasabah juga akan semakin meningkat. Hal tersebut disebabkan karena dari persamaan tersebut, apabila variabel Total Quality Management (TQM) atau X1 dinaikkan sebesar 1 maka tingkat Kepuasan Nasabah akan ikut meningkat sebanyak 0,903.

\section{b. Koefisien Determinasi $\mathbf{R}^{2}$}

Koefisien determinasi $\mathrm{R}^{2}$ atau koefisien determinasi ganda berguna untuk mengukur sumbangan variabel independen atau variabel bebas pada variabel dependen atau variabel terikat. Besar koefisien determinasi $\mathrm{R}^{2}$ terdapat diantara angka nol dan angka satu, atau dapat dirumuskan dengan $0<\mathrm{R}^{2}<1$. Berikut merupakan tabel output uji koefisien determinasi $\mathrm{R}^{2}$ dalam SPSS 23:

Tabel Hasil Koefisien Determinasi $\mathbf{R}^{2}$

Model Summary ${ }^{\mathrm{b}}$

\begin{tabular}{|l|r|r|r|r|r|}
\hline Model & \multicolumn{1}{|c|}{$\mathrm{R}$} & R Square & \multicolumn{1}{c|}{$\begin{array}{c}\text { Adjusted R } \\
\text { Square }\end{array}$} & $\begin{array}{c}\text { Std. Error of the } \\
\text { Estimate }\end{array}$ & Durbin-Watson \\
\hline 1 & $.901^{\mathrm{a}}$ & .812 & .809 & 2.08035 & 1.864 \\
\hline
\end{tabular}

a. Predictors: (Constant), TQM

b. Dependent Variable: KEPUASANNASABAH

Sumber: Output SPSS

Dari hasil koefisien determinasi $\mathrm{R}^{2}$ dalam SPSS 23 tersebut menunjukkan angka $\mathrm{R}^{2}$ sebesar 0,812. Angka tersebut menunjukkan bahwa Total Quality Management (TQM) dapat mempengaruhi Kepuasan Nasabah sebesar 81,2\%, dan sisanya yakni $100 \%-81,2 \%=18,8 \%$ berarti bahwa faktor lain yang tidak diteliti pada penelitian ini dapat mempengaruhi Kepuasan Nasabah sebesar $18,8 \%$. 


\section{Uji Hipotesis}

a. Uji T

Uji $\mathrm{T}$ dilakukan dengan tujuan untuk mengetahui signifikan atau tidaknya peran parsial variabel dependen $(\mathrm{X})$ pada variabel independent (Y). Untuk membuktikan signifikansi tersebut, digunakan uji $\mathrm{T}$ agar dapat menguji kebenaran ataupun kepalsuan Ho. Uji $\mathrm{T}$ dilaksanakan menggunakan program SPSS 23 dengan membandingkan nilai t-hitung dengan t-tabel yang memiliki siginifikansi 0,05 atau 5\%. Berikut merupakan tabel output uji T dalam SPSS 23:

\section{Tabel Hasil Uji T}

Coefficients $^{\mathrm{a}}$

\begin{tabular}{|c|c|c|c|c|c|c|c|c|}
\hline \multirow[b]{2}{*}{ Model } & & \multicolumn{2}{|c|}{ Unstandardized Coefficients } & \multirow{2}{*}{$\begin{array}{c}\text { Standardized } \\
\text { Coefficients }\end{array}$} & \multirow[b]{2}{*}{$\mathrm{t}$} & \multirow[b]{2}{*}{ Sig. } & \multicolumn{2}{|c|}{ Collinearity Statistics } \\
\hline & & $B$ & Std. Error & & & & Tolerance & VIF \\
\hline 1 & (Constant) & 4.341 & 2.247 & & 1.932 & .058 & & \\
\hline & TQM & .903 & .053 & .901 & 17.123 & .000 & 1.000 & 1.000 \\
\hline
\end{tabular}

a. Dependent Variable: KEPUASANNASABAH

\section{Sumber: Output SPSS}

Berdasarkan hasil tersebut, dapat terlihat bahwa nilai t-hitung variabel Total Quality Management (TQM) adalah 17,123, dan diperoleh nilai $\mathrm{t}$ tabel yakni sebesar 1,995. Disamping itu, nilai sig. juga menunjukkan angka sebesar 0,000 . Oleh karena itu, dapat ditarik kesimpulan bahwa t hitung lebih besar dari t tabel atau dapat dirumuskan dengan 17,123 > 1,995, dan nilai sig. lebih kecil dari 0,05 atau dapat dirumuskan 0,000 $<0,05$. Sehingga dapat dinyatakan bahwa hipotesis Ha diterima, atau dapat dinyatakan bahwa terdapat pengaruh positif antara total quality management (TQM) (X1) terhadap kepuasan nasabah perbankan konvensional Bank Tabungan Negara (BTN) KCP UIN Sunan Ampel Surabaya (Y1) secara signifikan.

\section{Pembahasan}

Dalam bagian pembahasan ini, penulis akan menganalisis hasil dari hubungan kausal antara variabel bebas dan variabel terkait dalam penelitian. Hal tersebut dilakukan sebagai pembuktian dari hipotesis yang telah dirumuskan oleh penulis, yakni dengan kata lain, bagian ini akan memberikan keterangan terkait apakah hipotesis yang telah dirumuskan dapat diterima atau ditolak. Pada bagian sebelumnya, penulis telah memaparkan hubungan dari total quality management (TQM) terhadap kepuasan nasabah yang berdasar pada penelitian terdahulu. Sedangkan pada bab ini, penulis juga akan memberikan analisa keterkaitan hasil dari penelitian terdahulu dan penelitian yang dilakukan oleh penulis.

\section{Pengaruh Total Quality Management (TQM) terhadap Kepuasan Nasabah BTN KCP UIN Sunan Ampel Surabaya}

Secara singkat, Total Quality Management (TQM) merupakan sebuah strategi manajemen organisasi yang memiliki tujuan untuk melakukan komitmen dalam kualitas melalui perbaikan yang dilakukan oleh seluruh anggota organisasi demi mencapai kepuasan pelanggan. Dalam implementasinya, perusahaan yang menerapkan TQM tentu berharap akan memiliki timbal balik yang didapatkan perusahaan, salah satunya adalah kepuasan nasabah. Oleh karena itu, dibutuhkan suatu kajian dalam terkait dengan pengaruh dari TQM, sehingga dapat memberikan wawasan dan pengetahuan baru bagi Bank Tabungan Negara (BTN) itu sendiri, khususnya dalam meningkatkan kualitas pelayanannya.

Dalam penelitian ini, Total Quality Management (TQM) memiliki pengaruh secara positif dan signifikan terhadap Kepuasan Nasabah. Pengaruh positif dan signifikan tersebut berarti, apabila TQM dinaikkan, maka kepuasan nasabah juga akan ikut meningkat. Hal tersebut dapat terlihat dari hasil dari uji $\mathrm{T}$ yang diperoleh angka t-hitung sebesar 17,123 dan sig. sebesar 0,000. Nilai tersebut 
menunjukkan bahwa terdapat pengaruh positif dan secara signifikan dari variabel independent/variabel bebas yakni Total Quality Management (TQM) terhadap variabel dependen/variabel terikat yakni Kepuasan Nasabah perbankan konvensional Bank Tabungan Negara (BTN) KCP UIN Sunan Ampel Surabaya. Disamping itu, adanya pengaruh juga dapat dibuktikan dari analisis regresi linier sederhana yang menghasilkan koefisien sebanyak 0,903, dimana hasil tersebut berarti bahwa apabila variabel Total Quality Management (TQM) atau X1 dinaikkan sebesar 1 maka tingkat Kepuasan Nasabah akan ikut meningkat sebanyak 0,903.

Hasil tersebut menunjukkan bahwa hipotesis Ha yang menyatakan bahwa "terdapat pengaruh positif antara total quality management (TQM) (X1) terhadap kepuasan nasabah perbankan konvensional Bank Tabungan Negara (BTN) KCP UIN Sunan Ampel Surabaya (Y1)" dapat diterima, dan hipotesis Ho yang menyatakan bahwa "tidak terdapat pengaruh positif antara total quality management (TQM) (X1) terhadap kepuasan nasabah perbankan konvensional Bank Tabungan Negara (BTN) KCP UIN Sunan Ampel Surabaya (Y1)" ditolak. Hasil tersebut sejalan dengan penelitian sebelumnya yang menunjukkan hasil bahwa Total Quality Management (TQM) memiliki pengaruh yang positif terhadap Kepuasan Nasabah, maka penelitian ini dapat memperkuat hasil dari penelitian terdahulu.

\section{KESIMPULAN DAN SARAN}

\section{Kesimpulan}

Berdasar pada hasil analisis yang telah melalui analisis data, uji asumsi klasik, uji pengaruh, dan uji hipotesis, maka dapat ditarik kesimpulan bahwa:

1. Hasil dari uji $\mathrm{T}$ yang diperoleh angka t-hitung sebesar 17,123 dan sig. sebesar 0,000 menunjukkan bahwa terdapat pengaruh positif dan secara signifikan dari variabel independent/variabel bebas yakni Total Quality Management (TQM) terhadap variabel dependen/variabel terikat yakni Kepuasan Nasabah perbankan konvensional Bank Tabungan Negara (BTN) KCP UIN Sunan Ampel Surabaya.

2. Hasil dari uji koefisien determinasi $R^{2}$ yang diperoleh angka $R^{2}$ sebesar 0,812 atau $81,2 \%$. Hasil tersebut menunjukkan bahwa Total Quality Management (TQM) dapat mempengaruhi Kepuasan Nasabah sebesar 81,2\%, dan sisanya dipengaruhi oleh faktor lain yang tidak diteliti pada penelitian ini yakni sebesar $18,8 \%$.

3. Hasil dari analisis regresi linier sederhana menghasilkan koefisien sebanyak 0,903. Hasil tersebut berarti bahwa apabila variabel Total Quality Management (TQM) atau X1 dinaikkan sebesar 1 maka tingkat Kepuasan Nasabah akan ikut meningkat sebanyak 0,903.

Secara keseluruhan, dapat ditarik kesimpulan bahwa Total Quality Management (TQM) secara signifikan dan positif dapat berpengaruh terhadap Kepuasan Nasabah. Hasil tersebut menunjukkan bahwa Total Quality Management (TQM) yang ada pada Bank Tabungan Negara KCP UIN Sunan Ampel Surabaya dapat mempengaruhi Kepuasan Nasabah. Namun, hasil tersebut juga tidak dapat secara menyeluruh dijadikan sebagai faktor utama dalam meningkatkan Kepuasan Nasabah, pihak manajemen Bank Tabungan Negara juga perlu melakukan analisa terhadap faktor-faktor lain yang tidak diteliti dalam penelitian ini.

\section{Saran}

Adapun terdapat saran bagi penelitian selanjutnya yang mengkaji tentang pengaruh dari Total Quality Management (TQM) yakni penulis berharap agar penelitian selanjutnya dapat melakukan penelitian dengan menggunakan lebih banyak indikator dalam pengukuran variabel penelitian. Hal tersebut bertujuan agar penelitian selanjutnya menjadi lebih baik dan lengkap. Selain itu, peneliti selanjutnya diharapkan tidak hanya terpaku pada pencarian pengaruh positif TQM terhadap Kepuasan Nasabah, tetapi juga dapat menggali pengaruh negatif TQM terhadap Kepuasan Nasabah. Sehingga pengaruh positif TQM tidak hanya dimaknai sebagai sebuah penilaian mutlak yang tidak dapat diperdebatkan tetapi ada 2 sisi TQM yang saling berkesinambungan antara pengaruh positif dan negatif yang mana 
nantinya akan membentuk operasional manajemen yang lebih baik. Penggambarang secara adil ini dapat lebih meningkatkan kredibelitas penelitian terhadap pengaruh dari TQM.

\section{DAFTAR PUSTAKA}

\section{BUKU}

Ghozali, Imam. (2013). Aplikasi Analisis Multivariate Dengan Program SPSS. Semarang: Badan Penerbit Universitas Diponegoro.

Ghozali, Imam. (2016). Aplikasi Analisis Multivariete Dengan Program IBM SPSS 23 Edisi 8. Semarang: Badan Penerbit Universitas Diponegoro.

Heizer, Jey. Barry Render. (2009). Operations Management Edisi Kesembilan, Jakarta: Salemba Empat.

Irawan, Handi. (2004). 10 Prinsip Kepuasan Pelanggan Cetakan Kelima. Jakarta: PT Alex Media Komputindo.

Kotler, Philip. Keller, Lane Kevin. (2000). Manajemen Pemasaran, edisi ketiga belas, jilid I dan II, terjemahan Hendra Teguh. Jakarta: Penerbit Prenhalindo.

Nasution, M. N. (2010). Manajemen Mutu Terpadu (Total Quality Management). Jakarta: Ghalia Indonesia.

Nasution, M. N. (2015). Manajemen Mutu Terpadu Thirteenth Edition. Jakarta: Ghalia Indonesia.

Nursalam. (2008). Konsep dan Penerapan Metodelogi Penelitian Ilmu Keperawatan: Pedoman Skripsi, Tesis, dan Instrumen Penelitian Keperawatan. Jakarta: Salemba Empat.

Rivai, Veithzal. (2008). Manajemen Sumber Daya Manusia Untuk Perusahaan: dari Teori dan Praktik. Jakarta: PT. Raja Grafindo Persada.

Supranto. (2009). Pengaruh Tingkat Kepuasan Pelanggan untuk Menaikkan Pangsa Pasar. Jakarta: Penerbit Rineka Cipta.

Sekaran, Uma. (2011). Research Methods for Business Edisi 1 \& 2. Jakarta: Salemba Empat.

Supriyanto, Achmad Sani. (2013). Metodologi Penelitian Sumber Daya Manusia Teori, Kuesioner, Dan Analisis Data. Malang: Uin Maliki Press.

Tjiptono, Fandy. Anastasia Diana. (1995). Total Quality Management. Yogyakarta: Andi.

Tjiptono, Fandy. (2009). Strategi Pemasaran, edisi kedua, cetakan ketujuh. Yogyakarta: Penerbit Andi.

\section{JURNAL}

Akila. (2017). Pengaruh Insentif dan Pengawasan terhadap Produktivitas Kerja Karyawan pada CV. Vassel Palembang. Jurnal Ecoment Global Volume 2 Nomer 2.

Baroroh, Utami. (2012). Analisis Sektor Keuangan Terhadap Pertumbuhan Ekonomi Regional di Wilayah Jawa: Pendekatan Model Levine. Jurnal Etikonomi Vol.11 No.2.

Donneli, Erry. (2018). Pengaruh Total Quality Management Terhadap Kepuasan Pelanggan Di Garden Gazebo Restaurant Purawisata Yogyakarta. Yogyakarta: Skripsi Fakultas Ekonomi UII.

Elan, Umi. Dina Harining Kusmindah. (2016). Pengaruh Total Quality Management Terhadap Kepuasan Pelanggan Pada Departemen Bubi (Bidang Usaha Barang Industri) Pt. Varia Usaha Di Gresik. Gema Ekonomi Jurnal Fakultas Ekonomi Vol.05 No.02.

Maddeppungeng, Andi. Rahman Abdullah. Ditta Dwi Kartika. (2016). Pengaruh TQM (Total Quality Management) dan SCM (Supply Chain Management) Terhadap Daya Saing pada Industri Konstruksi (Studi Kasus pada Kontraktor Bersertifikat ISO 9001 di DKI Jakarta). Jurnal Fondasi Vol.5 No.2.

Madona, Fitri. (2017). Pengaruh Kualitas Pelayanan terhadap Kepuasan Nasabah pada PT. Bank Syariah Mandiri Kantor Cabang 16 Ilir Palembang. Palembang: Tugas Akhir FEBI UIN Raden Fatah Palembang.

Mulyani, Ninuk. (2002). Tantangan Perusahaan di Indonesia dalam Menghadapi Pasar Global. Surabaya: Jurnal Widya Manajemen \& Akuntansi Vol.2 No.3. 
Setiawan, Bismar Harris. (2018). Total Quality Management (TQM) (Case Study: Analisis Akar Masalah Penerapan Teknologi Informasi dan Komunikasi (TIK) di Kabupaten Purbalingga). Yogyakarta: Tim Tata Kelola Sektor Publik MIP UMY.

Sukardi, Ria Amalia. (2016). Pengaruh Total Quality Management (TQM) Terhadap Kepuasan Pelanggan Pada Matahari Department Store di Plaza Mulia Samarinda. Samarinda: Jurnal Universitas Mulawarman, e-Journal Administrasi Bisnis Vol.4 No.3. 